\title{
BAHASA TUBUH PEREMPUAN \\ DALAM IKLAN KOSMETIKA DI TELEVISI \\ ( SEBUAH ANALISIS WACANA)
}

\author{
Gunawan Witjaksana dan Samudi \\ (wandira2008@yahoo.com) \\ Dosen Jurusan Ilmu Komunikasi STIK Semarang
}

\begin{abstract}
In the era of liberalization that characterized the television media with comodification various impressions to attract viewers, in many ways carried on various kinds of impressions displayed. No exception impressions cosmetic ads which in practice is clearly a lot of exploiting women's body language to attract the audience that they ultimately want to use the products offered. Cosmetics with herbs ad exploits women's bodies are often ignored ethics, especially related to KPI P3SPS and cultural and religious views of society and the rights of adolescents and women. The impact is certainly there was a negative. For that research using discourse analysis techniques to examine the use of body language in women's cosmetics advertisements on television to be attractive for the study. The goal is clear to see how the exploitation of women's body language in advertisements on television cosmetics. Through discourse analysis method of recording by cosmetics ads on television, and then analyzed by discourse analysis, it can be concluded that, of cosmetics advertisements on television were likely to utilize and exploit the perfect female body, in order to reach an audience sympathetic to using products that offered them. Unfortunately, the exploitation of women's body language in the cosmetics ads, less attention to ethical and religious views of the majority of Muslims in Indonesia, so the ad tend ignore the interests of general public and particularly children, adolescents, and women themselves.
\end{abstract}

Keywords : female exploitation

\section{Pendahuluan}

Pada era modern seperti sekarang ini, persaingan antar lembaga, terutama lembaga bisnis makin ketat. Berbagai lembaga bisnis tumbuh bak jamur di musim hujan. Dampaknya, tentu makin ketatnya persaingan di antara mereka, terutama untuk lembaga-lembaga bisnis dengan produk-produk yang sejenis. Berbagai kiat pun mereka tempuh, terutama guna memperkenalkan diri kepada masyarakat, sehingga berbagai produk yang dihasilkannya dikenal, diminati, dan akhirnya digunakan oleh masyarakat selaku konsumen. Ketatnya persaingan ini juga terjadi pada produk kosmetika yang pertumbuhannya juga sangat pesat.

Berbagai teknik marketing mereka gunakan baik melalui penonjolan kualitas produk (product), harga (price) yang terjangkau, tersedianya secara mudah di pasaran (place), pengepakan (packaging) yang menarik, serta yang paling gencar adalah melalui promosi (promotion), baik melalui teknik personal selling, sales 
promotion, atau yang saat ini paling menonjol adalah melalui iklan (advertising). Berbagai media mereka manfaatkan untuk advertising baik melalui media massa ataupun berbagai media lainnya.

Dari berbagai media yang mereka manfaatkan, tampaknya televisi merupakan media massa yang menjadi primadona, karena melalui aspek keserempakan antara gambar bergerak (motion picture) dengan suara, seolah hanya televisilah yang mampu menghadirnya kenyataan ke dalam ruangruang keluarga para pemirsa yang sedang santai. Berdasarkan penelitian Bovee dan Arens (1987) pengaruhnya bagai mengirim tentara dengan persenjataan lengkap masuk dan menembaki penduduk yang sedang santai dari pintu ke pintu. Melalui kekuatan televisi tersebut, orang sering menjadi tidak sadar, bahwa yang datang kepadanya melalui iklan televisi tersebut bukan realitas, melainkan sebenarnya adalah sekedar konstruksi dari realitas itu sendiri.

Begitu dahsyatnya dampak dari iklan televisi, sehingga media ini menjadi primadona bagi para pemasang iklan, termasuk perusahaan yang produknya kosmetika. Data tentang belanja iklan secara nasional yang pada akhir tahun 2007 menunjukkan besaran 34,1 triliyun rupiah ( AGB Nelson, 11 Maret 2008), 55 $\%$ nya (bahkan bisa lebih bila tidak dibatasi) terserap ke iklan televisi. Itu dilakukan oleh para pemasang iklan, termasuk lembaga bisnis yang produknya kosmetika, dengan keyakinan penuh bahwa bisnisnya akan sukses.

Berbagai iklan kosmetika pun sangat sering tampil di televisi dari yang berupa produk sabun mandi hingga berbagai produk shampoo yang mempertontontonkan indahnya rambut (padahal dalam Agama Islam rambut wanita termasuk aurat), yang terkait dengan berbagai bagian sensitif perempuan misalnya pembesar atau pengencang payudara, penyempurna vagina, atau hanya sekedar produk yang diperuntukkan mempercantik diri agar lebih menarik baik bagi calon pasangan hidupnya, penampilannya, hingga para suaminya.

Sayangnya, banyak produk kosmetika yang dalam penampilan iklan televisinya lebih menonjolkan bahasa tubuh yang sering menyerempet ke arah sensualitas yang tak jarang menuai protes, selain karena jam tayangnya yang tidak pas, menonjolan aurat sangat diharamkan dalam Agama Islam yang notabene merupakan agama dari mayoritas masyarakat Indonesia. Contoh-contoh kongkrit iklan itu misalnya iklan cream pembesar payudara produk Mustika Ratu yang dalam iklannya langsung memperlihatkan sensualitas payudara ikon pengiklannya. Demikian pula misalnya iklan produk Pounds yang seolah secara kurang logis seolah mampu menggagalkan pasangan yang telah hampir menuju jenjang pernikahan, lalu iklan Neo Hormoviton yang jelas menampilkan adegan yang syur yang cukup berlebihan.

Masih banyak lagi contoh iklan kosmetika televisi lainnya yang tekesan berlebihan dalam menonjolkan bahasa tubuh wanita sebagai daya tarik. Para pengiklan tentu yakin, bahwa teknik yang mereka gunakan tersebut cukup mujarab untuk mendongkrak omset penjualan 
produknya, sehingga berbagai produk lainnya pun seolah berlomba memanfaatkan dahsyatnya iklan televisi. Kondisi ini tentu sangat memprihatinkan dan perlu dibenahi. Oleh, karena itu, cukup menarik mengkajinya melalui penelitian ini.

Dengan latar belakang yang telah terurai, maka masalah pokok yang dikaji dalam penelitian ini adalah :

1. Bagaimana kondisi obyektif pemanfaatan bahasa tubuh perempuan dalam iklan kosmetika di televisi saat ini ?

2. Bagaimana eksploitasi bahasa tubuh perempuan yang dilakukan para pengiklan pada penampilan iklan kosmetika di televisi?

Penelitian dilakukan hanya menggunakan analisis wacana, maka tampilan iklan kosmetika di televisi tersebut setelah direkam melalui fasilitas TV Tuner di komputer, akan dianalisis dengan menggunakan berbagai dasar teori yang terkait dengan masalah ini. Penelitian ini dilakukan selain menghindarkan diri dari pendapat subyektif pengiklan, juga didasarkan pada penampilan obyektif iklan mereka di televisi yang telah berhasil direkam. Selanjutnya pengkajian secara mendalam melalui analisis wacana yang merupakan salah satu metode peneltian kualitatif dalam bidang komunikasi yang cukup diperhitungkan akurasi serta manfaatnya saat ini.

\section{Tinjauan Pustaka}

\section{Iklan Televisi}

Di antara berbagai iklan yang ditampilkan melalui media massa, maka iklan televisi dianggap sebagai primadona, karena sifatnya yang audio visual dengan memanfaatkan faktor keserempakan gambar bergerak dan suara (audio visual) serta makin pesatnya perkembangan teknologi "Special sound and picture effect" yang dimiliki stasium televisi (television broadcast). Maka kreativitas seperti apapun mampu ditampilkan iklan televisi. Lihat saja berbagai contoh misalnya tiba-tiba Asmuni mampu menjadi pemain Basket handal melebihi Michael Jordan, hanya sekejap setelah minum M150. Komeng yang tiba-tiba bak Superman yang mampu menyetop kontainer sesat setelah minum Hemaviton Energy dan banyak lagi iklan serupa lainnya. Hal yang seolah nyata tersebut tentu akan meimbulkan dampak yang luar biasa bagi pemirsa yang belum mengerti iklan (advertising minded), sehingga berdampak negatif bagi mereka.

Terkait dengan hal ini Bovee dan Arens (1986 : 435-439) menguraikan tentang kekuatan iklan televisi sebagai berikut:

1. Mass Coverage and low cost

2. Viewer emphaty

3. Selectivity

4. Deep Impact

5. Creativity, yang setidaknya muncul karena sifat televisi yang :

a. The picture must tell the story

b. Look for "key visual"

c. Grab the viewer attention

d. Be Single minded

e. Register the name of yor product

f. Reflect your product personality 


\section{g. Avoid talky comercial}

\section{Prestige \\ 7. Social Diminance}

Melalui uraiannya yang dilakukan berdasarkan hasil penelitiannya di AS setelah tahun 1986 tersebut, Bovee dan Arens menjelaskan bagaimana kuatnya dampak dari iklan televisi. Melalui jangkauannya yang sangat luas sehingga menjadi murah biaya serta tidak diperlukannya kemampuan empati tertentu dari pemirsanya, jelas iklan televisi akan mudah dimengerti, difahami, serta diikuti oleh siapa saja, meski mereka itu buta huruf. Bahkan iklan televisi justru mampu meningkatkan kemampuan emphati pemirsanya.

Selanjutnya kedalaman pengaruhnya digambarkan ke duanya bagai mengirim tentara dengan persenjataan lengkap menyerbu musuh yang sedang santai dan tidak siap dari pintu ke pintu. Dampaknya jelas sangat luar biasa, terutama bagi mereka yang belum advertising minded.

Kreatifitas seperti apapun mampu ditampilkan melalui iklan televisi, karena televisi didukung oleh teknologi special effect yang luar biasa pesat perkembangannya. Dengan demikian merubah manusia bak Superman, hingga seorang bisa keluar dari layar kaca mengambil sesuatu dan kembali masuk layar kaca untuk sebuah aktivitas biasa pun bisa dilakukan. Singkatnya, apapun maunya pengiklan, atau se-persuasif serta semenarik apapun yang diinginkan pengiklan, iklan televisi bisa mewujudkannya.
Menyajikan iklan di televisi pun akan mampu meningkatkan prestige dari lembaga pemasangnya. Sekaligus mampu menciptakan dominasi sosial di antara para pesaingnya. Dengan demikian, iklan televisi sering menjadi pilihan utama bagi para produsen yang merasa mampu.

Memperkuat pendapat ke dua pakar di atas, seorang konstruksionis Peter L Berger (dalam Little John, 1999) juga mengkategorikan pesan iklan merupakan konstruksi dari realitas. Pendapat pakar ini logis, karena dengan singkatnya waktu iklan televisi (15-30 detik yang dianggap efektif), maka tidak akan mungkin peristiwa yang berlangsung lebih dari sebulan (misal perubahan warna kulit) seolah menjadi sekejap. Bagi yang tidak memahami iklan televisi, hal yang sangat persuasif ini tentu akan mudah sekali mempengaruhi mereka, khususnya terhadap produk yang diiklankan tersebut. Banyak para psikolog yang antara lain New Comb, Turner dan Converce (1985) menyebut sebagai munculnya Unreal needs. Ini yang oleh banyak kalangan dituduhkan menjadi penyebab munculnya sifat konsumtifisme yang berlebihan.

2. Bahasa Tubuh

Idi Subandi Ibrahim (dalam Anang Hermawan, 2007:268) mengelompokkan konstruksi bahasa tubuh ke dalam dua wilayah yakni aura cewek macho dan cowok macho. Khusus untuk perempuan disebutkan juga oleh Anang Hermawan (2007:268) mendasarkan pada konsep orang Melayu yang melihat kecantikan dari atribut rambutnya yang bak mayang mengurai, ngandan-andan, kembang bakung, dan 
lain sebagainya. Demikian pula banyak kalangan yang sering mengaitkan iklan kosmetika dengan bentuk tubuh yang aduhai, kehalusan kulit dan sejenisnya.

Terkait ini, Anang Hermawan (2007: 268) menyebutnya sebagai komodifikasi tubuh perempuan dalam iklan, terutama iklan kosmetika. Dia selanjutnya juga berpendapat bagaimana iklan televisi mampu menumbuhkan "mediasi budaya pemujaan tubuh" (fetishm of body). Dalam konteks ini pula menurutnya muncul kecenderungan merebaknya tubuh yang ideal (yang dikonstruksi) sebagai sebuah mitos.

Pengkaji lainnya Muhamad Imam Zamroni (2007: 288) menyebut ketimpangan sosial (social disorder) menjadi penyebab pandangan yang membedakan kualitas perempuan dengan laki-laki. Itu muncul bahkan sejak era kolonial, di mana perempuan hanya dikaitkan dengan sektor domestik. Apa yang disebut Imam itulah yang tampaknya hingga saat ini banyak perempuan dijadikan obyek, termasuk keindahan tubuhnya demi menangguk keutungan yang besar melalui iklan televisi.

\section{Produksi Iklan Media}

Thomas Szase (dalam Johansen, 1990), menyebutkan karakteristik moral manusia adalah pengalaman ganda dari kebebasan berkehendak dan tanggung jawab pribadi. Keduanya merupakan aspek dari fenomena kebebasan dan tanggung jawab. Bila hal ini dikaitkan dengan iklan kosmetika di televisi yang memanfaatkan bahasa tubuh perempuan, maka semuanya kita kembalikan kepada siapa yang memproduksi dan apa tujuannya.

Matttew Kieran (1998) adanya beberapa faktor yang mempengaruhi para produser (termasuk produser iklan televisi) antara lain :

- Subyektivitas interpretasi

- Evaluasi subyektif

- Keterbatasan interpretasi obyektif

- Keterbatasan evaluasi obyektif

- Obyektivitas serta imparsialitas yang kuncinya antara lain adalah : menyajikan sesuatu yang simple dan resolveble, serta independensi dalam bekerja.

Merunut pada pendapat ke dua ahli tersebut tampaknya sangatlah sulit melepaskan sebuah produk (termasuk iklan kosmetika di televisi) dengan subyektivitas serta interpretasi produser, terutama terkait dengan kepentingan serta tujuan yang ingin dicapai. Bila hal ini kita kaitkan dengan pendapat Koentjaraningkrat (dalam Mentalitet dan Kebudayaan) tentang adanya mentalitet menerabas dari orang-orang dari wilayah timur, maka kemungkinan pemanfaatan bahasa tubuh perempuan dalam iklan kosmetika di televisi itu hanya sekedar jalan pintas yang mudah untuk mencapai tujuan, tanpa memperhitungkan dampak yang mungkin terjadi.

\section{Metodologi Penelitian}

1. Objek studi penelitian 
Objek studi dalam penelitian ini adalah iklan-iklan kosmetika di televisi. Untuk bisa menganalisisnya maka dilakukan perekaman secara detail dengan memanfaatkan perangkat komputer yang dilengkapi TV Tunner.

Setelah dilakukan perekaman, selanjutnya akan dikaji dengan menggunakan analisis wacana untuk mengetahui kondisi obyektifnya serta eksploitasi tubuh perempuan dalam menarik perhatian audiens. Dengan demikian penelitian ini hanya melakukan kajian terhadap teks iklan kosmetika televisi yang merupakan motion picture yang dilengkapi suara (audio visual), tanpa melibatkan pengiklan dan produsernya sebagai obyek kajian.

\section{Bentuk dan Strategi Penelitian}

Berdasarkan masalah yang diajukan, maka jenis penelitian dengan strateginya yang digunakan adalah penelitian kualitatif deskriptif. Dengan jenis penelitian ini, diharapkan mampu menangkap berbagai informasi kualitatif dengan deskripsi yang teliti, penuh nuansa natural (Lincoln dan Guba, 1985).

Karena penelitian yang dilakukan ini hanya terbatas mengkaji tampilan iklan kosmetika di televisi khususnya untuk selanjutnya akan dilakukan analisis wacana terhadapnya, maka digunakanlah strategi studi kasus tunggal terpancang (Sutopo, 2002). Disebut studi kasus tunggal terpancang karena permasalahan dan fokus penelitiannya sudah ditentukan lebih dahulu sebelum peneliti terjun menggali permasalahan di lapangan.

Penelitian yang telah dilakukan ini juga menggunakan pendekatan tafsir hermeneutic (Deddy Mulyana, 2001), dengan dilengkapi pendekatan kritik holistik (Sutopo, 1995). Pendekatan kritik holistik juga dilakukan dengan melihat 3 (tiga) faktor, yaitu faktor genetik, faktor objektif, dan faktor afektif. Faktor genetik merupakan faktor yang terkait dengan pola pikir produser iklan kosmetika televisi yang akhirnya menampilkan iklaniklannya. Faktor objektif terkait dengan kondisi objektif tampilan iklan kosmetika di televisi yang berhasil direkam. Dan, faktor afektif terkait dengan kajian yang akan peneliti (sekaligus penikmat) yang akan melakukan kajian menggunakan analisis wacana terhadap tampilan iklan kosmetika di televisi Dengan demikian metode analisis wacana yang digunakan ini juga memanfaatkan tafsir hermeneutik, dan hal ini sebenarnya sekaligus juga menyatu dengan pendekatan kritik holistik.

\section{Sumber Data}

a. Sumber data utama penelitian ini adalah dokumen hasil rekaman dengan memanfaatkan perangkat komputer yang dilengkapi $T V$ Tunner, yang selanjutnya akan dilakukan analisis wacana terhadapnya melalui tahapantahapannya. 
b. Agar analisis wacana ini lebih valid dan sahih, maka hasil observasi ditampilkan secara lengkap ketika iklan disisipkan pada tayangan utama. Data ini selanjutnya dapat digunakan untuk memperkuat hasil analisis.

\section{Sampling}

Penelitian ini menggunakan teknik cuplikan yang bersifat selektif, dengan menggunakan pertimbangan berdasarkan konsep teoretis yang digunakan, keinginan pribadi peneliti, karakter empiris, dan lain-lain. Oleh karena itu cuplikan yang digunakan dalam penelitian ini bersifat purposive sampling atau lebih disebut sebagai cuplikan dengan "criterion - based selection" (Goetz \& LeCompte, dalam Sutopo, 2002).

Dalam hal ini penelitilah yang akan memilih iklan-iklan kosmetika yang dipandang mewakili informasi yang dibutuhkan dari iklan kosmetika di televisi yang memiliki informasi serta tampilan lengkap. Dengan demikian, secara purposive sesuai dengan tujuan penelitian ini akan dipilih iklan kosmetika televisi dari sejumlah iklan yang berhasil direkam yang dipandang paling lengkap informasinya untuk dikaji.

\section{Teknik Pengumpulan Data}

Goetz dan LeCompte (dalam Sutopo, 2002: 58), menjelaskan adanya dua metode atau teknik, yaitu interaktif dan non-interaktif. Selanjutnya metode interaktif meliputi wawancara mendalam, observasi berperan dalam beberapa tingkatan, dan focus group discussion, sedang yang noninterkatif meliputi kuesioner, mencatat dokumen atau arsip (content analysis), dan observasi tidak berperan. Sesuai dengan bentuk penelitian kualitatif dan jenis sumber data yang dimanfaatkan, maka teknik pengumpulan data yang digunakan dalam penelitian ini adalah :

a. Mencatat dokumen (content analysis)

Teknik ini dilakukan dengan cara merekam iklan-iklan kosmetika di televisi, untuk selanjutnya setelah dipilih, dilakukan analisis wacana dengan menggunakan tahapan-tahapan sesuai dengan ketentuan metodologis pada model analisis ini. Melalui teknik tersebut akan diketahui bagaimana kondisi obyektif pemanfaatan bahasa tubuh perempuan di dalamnya, sekaligus untuk menganalisis adakah kecenderungan ekploitasi tubuh perempuan dalam penampilannya.

b. Observasi terhadap tampilan iklan itu ketika disisipkan pada tayangan utama, sehingga melalui cara ini akan dapat lebih didalami tujuan ditampilkannya iklan kosmetika di televisi tersebut.

\section{Pengembangan Validitas}

Penelitian yang telah dilakukan ini menggunakan pengembangan validitas trianggulasi seperti yang 
dikemukakan Patton (dalam Sutopo, 2002 : 78-79). Patton dalam hal ini menyebut adanya empat macam trianggulasi yaitu trianggulasi data (data tiangulation), trianggulasi peneliti (investigator triangulation), dan trianggulasi teoretis (theoretical triangulation). Menurutnya trianggulasi ini merupakan teknik yang didasari pola pikir fenomenologi yang bersifat multiperspektif.

Selanjutnya penelitian ini dilakukan dengan menggunakan teknik trianggulasi sumber, artinya selain analisis dilakukan terhadap hasil perekaman iklan kosmetika televisi, juga akan dibandingkan dengan tampilannya secara holistik di televisi saat iklan kosmetika itu ditampilkan. Itu dilakukan, selain dikaitkan dengan tingginya rating, juga segmentasi dari tayangan-tayangan utama di mana iklan kosmetika itu disisipkan.

\section{Teknik Analisis}

Penelitian ini dilakukan dengan menggunakan metode analisis wacana, Eriyanto (2002) setidaknya menyebut perlunya dilihat siginifikansi antara signifier dengan tujuan pesan itu (termasuk iklan kosmetika di televisi), terutama terkait dengan khalayak sasaran. Dengan melihat hal itu serta berbagai hal lain yang secara teoretis terkait, maka akan dihasilkan kajian yang lengkap serta mendalam, meski hanya dilakukan dengan cara mengkaji dokumen, karena pada hakekatnya justru dokumen itulah kenyataan yang terjadi pada iklan-iklan kosmetika di televisi saat ini.

\section{Kesimpulan}

televisi ternyata memang

memanfaatkan bahasa tubuh perempuan guna menarik perhatian serta simpati khalayak terhadap berbagai produk yang diiklankan tersebut. Pemanfaatan bahasa tubuh perempuan dalam iklan kosmetika di televisi juga cenderung dikaitkan dengan hal-hal yang lebih bersifat sensualitas seperti: bentuk tubuh, kehalusan kulit, serta berbagai gerakan, serta narasi dan musik yang terkesan dikaitkan dengan kepentingan lawan jenisnya. Dengan demikian terdapat kesan bahwa pemanfaatan bahasa tubuh perempuan dalam iklan kosmetika tersebut cenderung mengeksploitasi kondisi fisik tubuh perempuan melalui penampilan ikon iklan yang rata-rata wanita cantik, bertubuh aduhai dan populer. Tujuannya jelas yaitu agar khalayak tertarik dan membeli produk tersebut. Sayangnya penampilan produknya itu sendiri terkesan hanya mengekor kemolekan tubuh serta kepopuleran ikon iklan karena pada akhirnya yang diingat oleh khalayak lebih pada ikon iklan produk tersebut dibanding dengan produknya sendiri yang rata-rata hanya tampil dengan volume yang sangat minim.

Penampilan iklan kosmetika yang memanfaatkan bahasa tubuh perempuan tersebut terkesan masih mengabaikan etika, budaya, serta pandangan keagamaan masyarakat, karena penampilannya mengabaikan hampir sebagian besar P3SPS KPI, serta mayoritas masyarakat di 
Indonesia. Ke depan penampilan semacam ini perlu segera dibenahi agar meskipun tetap menarik tetapi pemanfaatan bahasa tubuh perempuan dalam iklan kosmetika di televisi perlu memperhatikan koridor P3SPS, serta kondisi riil masyarakat Indonesia sebagai khalayak.

Penyajian narasi dan musik sebagai pelengkap serta penguat iklan tersebut terkesan pula memperkuat kesan sensualitas, kemesraan adegan, serta mediasi budaya pemujaan bahasa tubuh demi tercapainya tujuan iklan tersebut sehingga kesan mengabaikan etika sangatlah kental. Sebenarnya tidak ada yang salah dengan pemanfaatan bahasa tubuh dalam iklan kosmetika di televisi selama bagian-bagian tubuh yang dimanfaatkan adalah bagian-bagian yang tidak sensitif, serta kesan sensual dan menarik lawan jenis bisa dikurangi.

\section{Daftar Pustaka}

Al Qur'an dan Terjemahannya. 2006. Bantuan Pemerintah Arab Saudi, Mekkah

AGB Nielsen Media Research. 2008. Komunikasi dan Edukasi tentang Survei Kepemirsaan TV "Apa dan Bagaimana Rating Menjadi Acuan Bagi Industri Periklanan dan Penyiaran TV. Ungaran: Dreamlight Studio.
Anang Hermawan. 2007. Artikel Ilmiah, Membaca Iklan Televisi: $\quad$ Sebuah Perspektif Semiotika. Jurnal Komunikasi Progdi Komunikasi UII. Yogyakarta: Progdi Ilmu Komunikasi.

Bovee Courtland L. \& Arens William F. 1986. Contemporary

Advertising. Second Edition, Homewood Illinois : IRWIN.

Dedi Mulyana. 2001. Metodologi Penelitian Kualitatif, Paradikma Baru Ilmu Komunikasi dan Ilmu Sosial Lainnya. Bandung: PT. Remaja Rosda Karya.

Eriyanto. 2002. Analysis Framing, Konstruksi, Ideologi, dan Politik Media. Yogyakarta: LKIS.

Eriyanto. 2001. Analisis Wacana. Yogyakarta: LKIS.

Johansen, Ricard L. 1990. Etika Komunikasi. Bandung : Rosdakarya.

Kieran Matthew, Edit. 1998 Media Ethics. New York: Routledge.

Little John, Stephen W. 1999. Theories of Human Communication, Sixth Edition. USA: Wadsworth Publishing Company.

Lincoln, Yvonna S. \& Guba, Egon

G. 1985. Naturalistic Enquire. London: Sage 
Publications Berverly Hills.

Muhammad Imam Zamroni. 2007. Artikel Ilmiah, Kapitalisasi Tubuh

Perempuan dalam Iklan Televisi. Jurnal Komunikasi Progdi Komunikasi UII. Yogyakarta: Progdi Ilmu Komunikasi.

Newcomb, Theodore M; Turner, Ralph H; Converse, Philip E. 1985. Psikologi
Sosial. Bandung: CV. Diponegoro.

Pedoman Penyelenggaraan Penyiaran dan Starndart Program Siaran (P3SPS). 2005. Jawa Tengah: Komisi Penyiaran Indonesia Daerah Propinsi Jawa Tengah.

Sutopo H.B. 2002. Metodologi Penelitian Kualitatif, Dasar Teori dan Aplikasi Praktisnya. Surakarta: Sebelas Maret University Pers 